\title{
AGAINST RUSKIN
}

\section{Joseph and Elizabeth Pennell's recasting of Venice}

[Received August 28th 2020; accepted March 1st 2021 - DOI: 10.21463/shima.116]

\section{William Bainbridge}

University of Hertfordshire, UK <w.bainbridge@herts.ac.uk>

\begin{abstract}
The images of Venice by Philadelphian Joseph Pennell (1857-1926) have never really escaped from James McNeill Whistler's long shadow. His etchings, drawings, pastels, and lithographs all show the influence of the master. Together with his wife, Elizabeth Robins Pennell (1855-1936), he would publish a two-volume biography of his friend (1908). Their allegiance to Whistler and the Barbaro Circle brought the Pennells to endorse a new image of Venice away from the hegemonic cult of Ruskin pervasive in tourist and travel books about the city. This article seeks to reassess the contribution of both Pennells to this group of erudite intellectuals and reconsider their promotion of a more truthful and intimate representation of Venice beyond the mass of tourists and polished marble façades. Its special focus is on the Pennells' - Elizabeth's in particular - antagonistic relationship with Ruskin, whose iconic The Stones of Venice had mourned a city forever lost to tourists, overrestoration, and the onslaught of the railroad.
\end{abstract}

KEYWORDS: Joseph Pennell, Elizabeth Pennell, John Ruskin, James McNeill Whistler, John Singer Sargent

\section{Introduction}

Ruskin's The Stones of Venice (1851-1853) classically formulates a strong argument against the destruction wrought upon the aesthetic and environmental integrity of the maritime city in the 19th Century. Chief among Ruskin's concerns were those damaging forces linked to the onslaught of mass tourism and the railroad. ${ }^{1}$ While promoting Venice as a tourist destination in its own right, however, Ruskin also argued that it was precisely tourism that was responsible for the city's demise (Hanley, 2010). Rooted in an older style of travel, influenced by a legacy of cosmopolitanism instilled by the practices of the Grand Tour, his manifesto for preserving the architectural heritage of Venice was nostalgic towards those "olden days of travelling, now to return no more, in which distance could not be vanquished without toil, but in which that toil was rewarded" (Works, 10:3).

Venice, the city of contrasts and contradictions, was under threat from the heavyhandedness of the restorer and the aspirational modernism of the town planner, both forever too keen to render their efforts in a way that would tarnish the essential qualities of the city irredeemably. Writing to his father in September 1845, he pointed repeatedly to calamities annihilating Venice brought about by decay - the palaces on the Grand Canal appeared to

\footnotetext{
${ }^{1}$ The railway bridge from Venice to the mainland was built during the Austrian occupation and inaugurated in 1846 , but, by the time of Ruskin's visit in 1845 , it was already possible to walk across it (Greenfield, 1939: 315; Clegg, 1981: 55).
}

Shima <www.shimajournal.org > ISSN: 1834-6057 
him as "mouldering down as if they were all leaves and autumn had come suddenly" (Shapiro, 1972: 198; Clegg, 1981: 56). The seductive image of Venice, reflected as a "mirage on the lagoon", would be no more (Works, 9: 17) - the city itself sunk under the weight of tourists, strolling through its streets with Murray, Cook, and Baedeker guidebooks in hand (Palmowski, 2002).

Ruskin was not alone in his pathos-ridden battle cry towards persevering the essence of Venice, as indefinable and ambiguous it might be. The Stones of Venice certainly cemented his authority on the plight of the city. But the decline of Venice was not only due to tourism. It was also subject to environmental conditions, such as the relentlessly fluctuating waves of the Adriatic - a hot topic frequently discussed in contemporary geographical scholarship (Fletcher and Spencer, 2005; Madricardo and Donnici, 2014). Acting as an allegorical statement on the moral condition of society and urban malaise in general, his book was not a travel guide in the traditional sense, but its prevailing influence on tourism in Venice is undeniable (Bosworth, 2015). Elizabeth Robins Pennell (1855-1936), for instance, makes it clear that she and her artist husband Joseph (1857-1926) were partly drawn to Venice because of Ruskin. She ultimately rejects, however, the way in which Ruskin's legacy equipped individuals with all too specialised tools to experience it.

In this essay, Elizabeth and Joseph Pennell offer a quieter yet important voice in this debate - a starting point from which Ruskin's influence upon Venice studies might be regarded as less pervasive. In staging the dialogue between Ruskin and the Pennells in tentatively antagonistic terms, I seek to find clues for casting a new gaze over the city, offering historians of 19th Century Venice as well as those concerned with Venice's current environmental fragility, a different set of tools to decode its tourist maze (Settis, 2016; Davis and Marvin, 2004). This gaze has the potential of recasting Venice away from those overused tropes and hackneyed images that rendered the city almost as a canovaccio ${ }^{2}$ open to improvised interpretations by everyone and anyone.

These tropes and images were often coloured by words that have now become almost prosaic in their stereotypical formulation, furnished with quotations penned by a 'puritanical' Ruskin or a 'heroic' Byron, and illustrated by the detailed eye of Canaletto or the atmospheric mystery of Turner. The Pennells were simultaneously part of the system which promoted these now familiar tropes, not least by their connection to a gilded circle of Anglo-American intellectuals and artists centred at Palazzo Barbaro, but they were also part of a different system that opposed established models for viewing Venice. Their books and art sought to devise an alternative framework for reorganising the signs and symbols attached to Venice at the turn of the century, away from the mould of standard typecasts and clichés to which Ruskin was often reduced in the literature for the tourist market.

\section{Ruskin's Heritage Machine}

The Pennells were clearly influenced by Ruskin in both their independent and collaborative work. It appears, however, that such influence was more indebted to the aura surrounding Ruskin in the Anglo-American circles in Venice than to a careful study of his works. Joseph, for instance, openly acknowledged Ruskin's impact upon his ways of looking: "Ruskin's descriptions woke me up and made me see things"; but he also admitted not to have read

\footnotetext{
${ }^{2}$ A type of scenario used by commedia dell'arte actors allowing for improvisation in their plays.
} 
much in its entirety ("I never got completely through anything"), with the exception of The Elements of Drawing (Pennell, 1925: 74). He, nonetheless, uses Ruskin's quotations prominently as an ideal commentary to the drawings and etchings featured in his Venice, the City of the Sea (1913a). In Elizabeth's Nights: Rome, Venice, in the Aesthetic Eighties; London, Paris, in the Fighting Nineties (1916), the critique towards Ruskin is actually levelled against his influence on the Anglo-American communities in Venice. Her criticism, however, reveals also a reaction towards the somewhat blithe hold that Ruskin possessed over female creativity and the "Ruskin-boomed amateurs" formula, sometimes too quickly linked to women (Pennell, 1895: xvii; Nunn, 2000: 176).

Needless to say, like many others writing about Venice or depicting it in art at the turn of the century, the Pennells were keen of course to acknowledge Ruskin's authority, poetically and aesthetically, in order to convey greater credibility to their own works. By the time of the two above-mentioned publications, printed a generation after The Stones of Venice, Ruskin still held sway over literary and artistic portraits of Venice (Clegg, 1981; Hewison, 2009). Ruskin was an unavoidable name in guidebooks and travel writing on the city, independently from the position their authors might have taken on him. Now as then, histories and guides on Venice do not fail to mention him (Morris, 1960; Norwich, 2004; Ackroyd, 2009; Dragicevich and Hardy, 2020). As a youth, aspiring to enter Philadelphia's Academy of Fine Arts, Joseph read Ruskin's Modern Painters and even sent work to him for his approval, without getting any reply (Young, 1970: 82). This early anecdote is indicative of his long and complicated relationship with the Victorian art critic, which he shared with his wife. Throughout their writings, Ruskin appears as an easy target for forging their own identity as art critics.

During his extended visit to Venice in 1845, Ruskin found the scene of Venice much changed since his stay there four years before (Clegg, 1981: 51-62). He was still able to recognise elements of the scenery as if rendered by Turner, "the greatest of all landscape painters", whereby colour, light, buildings, and water coalesced in a unique vision (Works, 3: 530). ${ }^{3}$ This time, however, Ruskin was shocked at the sight of the new bridge connecting Mestre and Venice, bringing cold modernity directly into the city hitherto free from the steam engine and gas light (Pertot, 1988: 15-19). He wrote to his father despairingly of the scene he encountered:

But to return to the grand canal, it began to look a little better as we got up to the Rialto, but, it being just solemn twilight, as we turned under the arch, behold, all up to the Foscari palace - gas lamps! on each side, in grand new iron posts of the last Birmingham fashion, and sure enough, they have them all up the narrow canals, and there is a grand one, with more flourishes than usual, just under the bridge of sighs. Imagine the new style of serenades - by gas light. Add to this, that they are repairing the front of St. Mark's and appear to be destroying its mosaics. (Shapiro, 1972: 198-199)

The "golden city, paved with emerald" he had experienced before, was vanishing, along with the utopian fantasy that Britain might emulate it one day in its essence - Venice was in fact becoming more like Birmingham or Liverpool and not the other way around. But the

\footnotetext{
${ }^{3}$ In Modern Painters, Ruskin instructs his readers who have "not been at Venice" to seek out Turner's painting 'The Sun of Venice Going to Sea' (1843), now in the Tate, to garner an impression of the Venetian waterscape and its interplay with light and colour (Works, 3: 545-546).
} 
"Greenwich railway", to which he equated the new bridge to the terraferma, was not the only concern:

When we entered the Grand Canal, I was yet more struck, if possible, by the fearful dilapidation which it has suffered in these last five years. Not only are there two-thirds of the palaces under repair - we know what that means, but they could not stand without it; they are mouldering down as if they were all leaves and autumn had come suddenly... Of all the fearful changes I ever saw wrought in a given time, that on Venice since I was last here beats... The Foscari palace is all but a total ruin - he rents in its walls are half a foot wide. The interior court of the Doge's palace... is being repaired - covered with scaffolding, and as a preparatory step they have already knocked off the heads of the statues... The front of St. Mark's is being fitted with grand new windows, and the exterior arcade of the Doge's palace has been brilliantly whitewashed inside, splashing the capitals all over, - breaking most of them. (Works, 4:40-41)

What Ruskin saw amounted to destruction. Romantic decay could possibly be accepted, but the ham-fisted restoration taking place, so much so that the storied layers of Venice were being whitewashed, was not. The text and accompanying sketches, therefore, provided The Stones of Venice with a timely record of the city - a heritage manifesto by another name before the Gothic magic was hopelessly lost (Hewison, 2000: 55). The horrors of modernisation, the decay of palaces, and the scandal of restoration all threatened to stain the Byronic atmosphere he experienced previously - the weeds sprouting from masonry no longer provided the agreeable signs of the picturesque. ${ }^{5}$

Ruskin, however, was still writing after a succession of earlier English authors and artists, equally fascinated by Venice, and as such his material about the city is imbued with the expansive romantic imagery of those who went there before. Lord Byron, Walter Scott, Samuel Rogers, whose poem 'Italy' first appeared in 1822, and Turner, without neglecting Shakespeare, acted as his ideal guides (Ross, 1994; George, 1971; Holcomb, 1988). Ruskin could be placed at the beginning of a new chain of literary evocations which made of Venice a topic sui generis, further expanded upon by Dickens' Venetian chapter, "An Italian Dream", in his Pictures from Italy (1846), George Sand's novel Leone Leoni (1833), and, later, Wilkie Collins' The Haunted Hotel: A Mystery of Modern Venice (1879), to name but a few. ${ }^{6}$

"My Venice, like Turner's, had been chiefly created for us by Byron", Ruskin states, "but for me, there was also still the pure childish passion of pleasure in seeing boats float in clear water". "Shakespeare's Venice" might have struck him as "visionary", but Byron reanimated for him "the real people whose feet had worn the marble I trod on" (Works, 35: 295, 151). In Canto IV of Byron's poem 'Childe Harold's Pilgrimage', the poetic imagination provides the one possible assuage against time's universal deluge: Venice was "as a fairy city of the heart/

\footnotetext{
${ }^{4}$ This account is starkly contrasted to the Ruskin's vivid account of arriving in Venice at the opening of the second volume of The Stones of Venice where he suggests that "when first upon the traveller's sight opened the long ranges of columned palaces, - each with its black boat moored at the portal, - each with its image cast down, beneath its feet, upon that green pavement which every breeze broke into new fantasies of rich tessellation; when first, at the extremity of the bright vista, the shadowy Rialto threw its colossal curve slowly forth from behind the palace of the Camerlenghi" (Works, 10: 6).

${ }^{5}$ For an overview on the restoration campaigns in Venice in Ruskin's time, see Pertot (1988: 11-53).

6 Although Byron and Rogers are relevant as early influences, Ruskin subsequently moved away from these.
} 
Rising like water-columns from the sea” (18, 1l. 155-156; McGann, 1994: 153). Venice becomes for Ruskin, as it did for Byron, the "imagination's symbolic capital, a magic breakwater against the relentless, cosmic down-drift” (Ross, 1994: 115).

Ruskin's example illustrates the intimate relationship that Venice was able to establish between travel, history, and literature. His gaze was saturated with images and words that Byron and Rogers, for instance, used in describing their tours. This combination between real travel and imaginary pilgrimage follows a template already popular during the Grand Tour, which would later serve as a model for Ruskin (Helsinger, 1982: 145). He was not alone in harnessing that legacy. After the Battle of Waterloo, picturesque and poetic viewing became increasingly relevant to travel. Italy was in vogue once again - travelling to it offered the opportunity to delve into a classical past, where historical events could be relived through poetic memories (Redford, 1996:32-35). As Mary Shelley reported as early as in 1826, "it was the paramount wish of every English heart, ever addicted to vagabondizing, to hasten to the Continent, and to imitate our forefathers in their almost forgotten custom, of spending the greater part of their lives and fortunes in their carriages on the postroads of the Continent" (Shelley, 1826:325; Buzard, 1993: 80). A good example of this Grand Tour revival is offered by Rogers, who framed his poem 'Italy' as an appeal "to those who have learned to live in Past Times as well as Present, and whose minds are familiar with the Events and the People that have rendered Italy so illustrious" (1854: 221; Sandy, 2021).

The Stones of Venice satisfied a different market, however, to that of Byron or Rogers. It was neither a literary or poetic work, or a travel book, nor was it a book for amateurs, or those "seeking a comfortable architectural guide for chaperoned young ladies absorbing culture in the ethereal world of Rogers' marble-banked and shimmering canals" (Cosgrove, 1979: 156). It ranks, however, as one of the most enduring publications on Venice to combine travel, history, and art in a rigorous way. At the other end of the market, operating mainly for the increasingly affluent middle classes (of which Ruskin was a member), existed those travel guides that dealt in facts, figures, and more restrictive routes systematised by objects and places - numbered routes not to be deviated from - by the likes of Murray and Baedeker, who begun producing guidebooks in the 1830 (Goodwin and Johnson, 2013). They too, like Ruskin, were keen to couch their suggested routes along the lines established by recognisable and fashionable names, like Byron's, and the sites they experienced along the way, but in more much methodical way (Buzard, 1991).

Despite the contrast between these two genres of writing about travel, they both acted in tandem to provide a collective sense of 'how to travel' in the 19th Century (Damien, 2010). In the hermetic world of 19th Century travel publishing, it made sense that mutually beneficial cross-referencing took place. Ruskin offered Murray's early editor, Francis Palgrave, for instance, commentary about mediaeval art, but shared with him a general concern over factual inaccuracies and the stress on hurriedness in travel present in the Handbook: "[i]n my last edition of Murray's Guide to Northern Italy, I find the visitor advised how to see all the remarkable objects in Venice in a single day" (Works, 11:36o). ${ }^{7}$ Ruskin, instead, suggested himself as the arbiter of taste in aesthetics for the discerning romantic traveller, away from vulgarity and superficiality connected to the unsophisticated style of travel of the new and business-like tourist.

\footnotetext{
${ }^{7}$ Correspondence between Murray and Ruskin in 1845-1846 about the first edition of Murray's Handbook for Travellers in Northern Italy is available in the Murray Archives, National Library of Scotland, Edinburgh, MS42613. Ruskin contributed a few notices to the 1846 and 1847 editions; see also Tucker (1996).
} 


\section{Golden Circles}

Joseph Pennell was a more talented artist than usually suggested. Although his art is taking on a more significant position in recent scholarship, he certainly made Venice more accessible to a wider public, but he was also seminal in promoting the Alps as well as sites in France and England (Pennell, 1909; Schuyler Van Rensselaer, 1892; Young, 1970; Bainbridge, 2018). Central among his artistic publications, the already mentioned Venice, the City of the Sea (1913a), was particularly successful for introducing Venetian architecture of the Old World to the New World, paying a special attention to those sites and scenes he thought were at risk of "passing away", expressing a nostalgia for "a world and an age which he thought was lost forever with the war" (Bye, 1928: 226, 223). These concerns stood in strong contrast to his illustrations of Philadelphia and its industrial outlook, New York and its skyscrapers, or even London, which became Elizabeth and Joseph's permanent base in Europe from 1884 to 1917 (Pennell, 1912, 1913, 1914). As an illustrator of cathedrals but also factories, he was revolutionary in the way he experimented with various publishing techniques, such as chromolithography on different types of paper (Pennell, 1896). He was a pioneer of the art of transferring a sketch to stone, while retaining the original features intact (Morenus, 2004; Palumbo, 1986). Frederick Keppel clearly thought his qualities were sufficient enough for him to publish a small volume in his honour at the peak of Pennell's career, with the intention of promoting him to a level of distinction enjoyed by other "famous artists of American birth" (1907: 9).

No matter how lavish the words used to describe Pennell's work might have been "greatness", "genius", "versatility", "uniformly high level" - his reputation remained eclipsed by the art of his friend James McNeill Whistler. ${ }^{8}$ Their friendship and collaborative work, which blossomed in London, is the reason why their names were often placed together. The partnership was cemented early, around the time of Whistler's exhibition of twelve etchings known as the 'First Venice Set' at the Pennsylvania Academy of the Fine Arts in 1881. Both artists were talented etchers and lithographers, and Whistler's art, like Pennell's, is often associated with Venice. It is to Whistler that both Pennells turn; it is Whistler who inspired them; but it is the Pennells who promoted Whistler's reputation rather than the other way around. Elizabeth and Joseph jointly authored the definitive two-volume biography of Whistler in 1908: "Pennell never really escaped from Whistler's shadow and his etchings, drawings, pastels and lithographs all show the influence of 'The Master"' (Halsby, 1999: 107). For over thirty years, the Pennells travelled to Italy and Venice from London, producing books on their own and illustrating those of others, including Marion Crawford's bestseller Gleanings from Venetian History (1905).

Joseph and Whistler, however, had different attitudes towards art. Pennell was more inclined to depict the 'real world', while Whistler was considered more "the protagonist of art for art's sake, art not for the public but for the few" (Bye, 1926: 223). Elizabeth herself admits that the influence of Whistler on her husband was extensive. In her The Life and Letters of Joseph Pennell, she maintained that Joseph "loved Whistler, believed in Whistler's art, was steadfast in his loyalty" (1929, 1: 348). If anything gives an impression of how highly Joseph himself regarded Whistler, his own phrase "The two great etchers were Whistler and Rembrandt" might be it (1921: 144). Pennell goes on to place a plate of both artists side by side for

\footnotetext{
${ }^{8}$ See, for instance, also 'The Joseph Pennell Memorial Exhibition' in The Bulletin of the Cleveland Museum of Art (1927: 67): "[Pennell's] work has more than technical perfection; it often recreates the illusion of the original”; his art is often displayed in Whistler-related exhibitions (Denker, 2003).
} 
comparison. ${ }^{9}$ Whistler was the admiration of his life, and the monument to this is the biography he wrote with his wife (1908).

The Pennells were also connected to John Singer Sargent, another artist of lasting repute often associated with Whistler and Venice in equal measure. Through Sargent, Whistler and the Pennells became part of a gilded circle of artists and intellectuals that made up an elite segment of the Anglo-American community centred at Palazzo Barbaro on the Canal Grande, home of Daniel and Ariana (Sargent) Curtis (MacCauley, 2004). ${ }^{10}$ Here, the Curtises would entertain figures such as Isabella Stewart Gardner, Bernard Berenson, and the British poet, Robert Browning, who along with his sister Sarianna would make his home at his son Pen's Ca' Rezzonico after the death of his wife. It is in Venice that Sargent would create some of his most successful and original works, including the acclaimed 'Venetian Interior' (18801882 - Figure 1), known for its "virtuoso play of light and subtle and monochromatic tones" (Halsby, 1999: 115).

Sargent, who was deeply impressed by Whistler after meeting him in Venice in 1880, offered new types of views of the city, which were less typical, less romantic, less Ruskinian than usual. Together with Pennell's art, in Sargent and Whistler we see an increasing focus on forgotten calli (alleyways) and campi (squares) of the everyday Venice set aside from the glamourous canals, campaniles (bell towers) and palaces familiar to routes guided by Murray and Ruskin, away from the well-beaten path (Honour and Fleming, 1991). Of Sargent's approach to representing Venice, Halsby has noted that his main theme was

working Venetian girls seen in the cool light of shuttered interiors. The heat outside suggested by subtle rays of light; the tonal values inside are brilliantly orchestrated. There is nothing romantic about these pictures. The girls engaged in boring and repetitive work such as stringing beads or working with glass have no contact with the world of sightseeing and grand hotels beyond the shuttered windows, and in their emphasis upon the ordinary people of Venice, the pictures relate to the Realist Movement. (1999: 114)

And yet, this description of a new turn identified in Sargent could also be applied to the work of Whistler and Pennell. To this somewhat superficial review of the 'golden circle' to be found at Palazzo Barbaro, however, should also be added the name Henry James, another American to be repeatedly seduced by the city from his first visit in $1881 .{ }^{11}$

\footnotetext{
${ }^{9}$ See also Pennell (1919: 29): "The reason why these two artists occupy the places they do is because they employed - Whistler more, Rembrandt less - their genius, and the art of etching in the right way".

${ }^{10}$ Ruskin's entry for the palace reads "on the Grand Canal, next the Palazzo Cavalli. These two buildings form the principal objects in the foreground of the view which almost every artist seizes on his first traverse of the Grand Canal, the Church of the Salute forming a most graceful distance. Neither is, however, of much value, except in general effect; but the Barbaro is the best, and the pointed arcade in its side wall, seen from the narrow canal between it and the Cavalli, is good Gothic of the earliest fourteenth century type" (Works, 11:363).

${ }^{11}$ The literary circles and salons active in Venice should not be restricted to Palazzo Barbaro and its Anglo-American attendees. The conversazioni at Palazzo Dario, for instance, just opposite Palazzo Barbaro, were attended by Sargent, Walter Sickert, and Vernon Lee (Schwander, 2008: 21; Halsby, 1999: 118-119).
} 


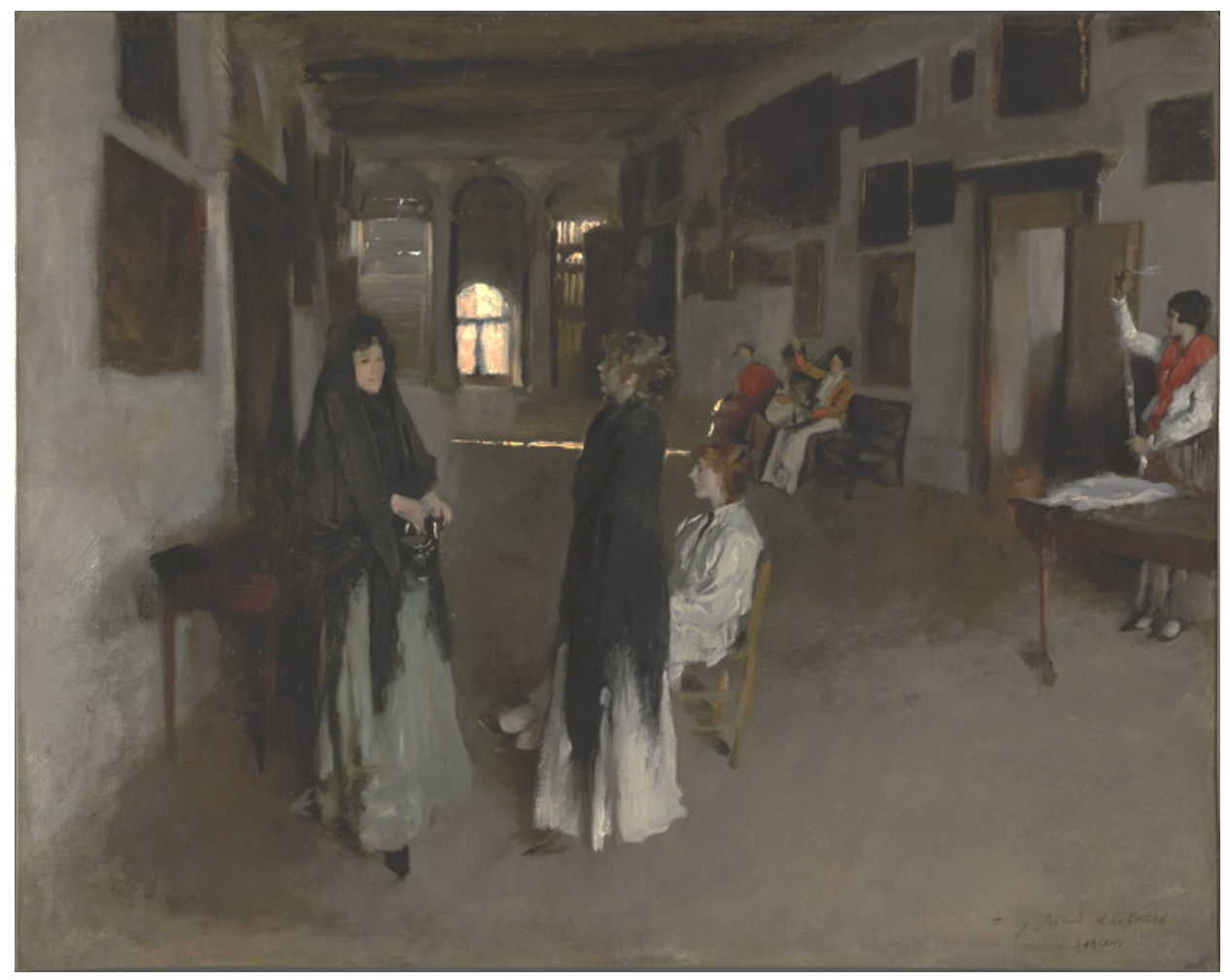

Figure 1 - John Singer Sargent 'A Venetian Interior' (1880-1882) - Williamstown, The Clark Art Institute.

James' collection of travel essays, Italian Hours (1909), whose opening chapters were devoted to the Venice, was illustrated in pastel by Pennell (Graham, 2003: 5). James may well have arrived in Venice regarding it as a shrine, laden with Byronic and sensual expectation, but his works perfectly fit the aesthetic atmosphere which pervades Pennell's and Whistler's depictions of Venice. James' understanding of the powerful symbolism of the city is marked at the beginning of Hours when he states that "Venice has been painted and described many thousands of times, and of all the cities of the world is the easiest to visit without going there" (1909: 3). ${ }^{12}$ Like Ruskin, he is concerned for the plight of the city which is increasingly becoming a pleasure-house for the mass-market, sold as a Disneyland before Disney.

The city's uniqueness is marketed and exploited. But this exploitation acts only for the negation of its very uniqueness:

The Venice of to-day is a vast museum where the little wicket that admits you is perpetually turning and creaking, and you march through the institution with a herd of fellow-gazers. There is nothing left to discover or describe, and originality of attitude is completely impossible. (ibid: 7-8)

\footnotetext{
${ }^{12}$ In his essay "Remembering Venice", Hartley argues that "there is not... another city in the world where cartography and actuality bear so little relation to one another" (1967: 209).
} 
The Jamesian and Ruskinian visitor is similarly dogged by "the vexatious sense of the city of the Doges reduced to earning its living as a curiosity shop" (ibid: 16). In another echo of what Pennell, Whistler, and Sargent seem to attempt in art, James seems wholly to acknowledge in text that the image of Venice is product of an artificial naturalness:

Nowhere... do art and life seem so interfused and, as it were, so consanguineous. All the splendour of light and colour, all the Venetian air and the Venetian history are on the walls and ceilings of the palaces; and all the genius of the masters, all the images and visions they have left upon canvas, seem to tremble in the sunbeams and dance upon the waves. That is the perpetual interest of the place that you live in a certain sort of knowledge as in a rosy cloud. You don't go into the churches and galleries by way of a change from the streets; you go into them because they offer you an exquisite reproduction of the things that surround you. (ibid: 25)

The city known by everyone becomes known by everyone not because it is the attractive object of a particular gaze but because it offers the medium through which that gaze is transmitted. The great Renaissance masters, such Titian or Tintoretto, are reappraised through the lens of this 'new' Venetian School both in art and literature. This new school educated the visitor to experience Venice not in the manner of a Ruskinian connoisseur anymore, "but as a man of the world" (ibid: 26). Venice is a city often connected to the real and metaphoric result of reflections, but in this new manner of seeing its urban and maritime landscape the roles of scene and the spectator are momentarily reversed. ${ }^{13}$

\section{Frauds}

Elizabeth Robins Pennell was an equally successful independent writer and critic as her husband was as an independent artist. She wrote for New York's Nation and Atlantic and London's Pall Mall Gazette, among others, publishing many monographs of her own (including many about gastronomy), among which features the biography of proto-feminist Mary Wollstonecraft (1884; Jones, 2016). ${ }^{14}$ She collaborated with Joseph extensively on various books, including articles for the Century Magazine, with texts accompanying several of Joseph's illustrations. Their work always reflected a mutual passion for graphic arts and illustration, and, more latterly, because of Joseph's aesthetic alignment and friendship with Whistler, they contributed to establish a popular cult around the artist. These aesthetic concerns were also inflected in the more light-hearted approach featured in some of their travel writing, in which they retraced the route of Chaucer's Canterbury Tales (1885), Laurence Sterne's A Sentimental Journey Through France and Italy (1888), or, as an amusing attack against the Alpine Club's climbing orthodoxy, Over the Alps on a Bicycle (1898). ${ }^{15}$

Their collaborations offered a new way of gazing upon Venice, which combined the modernist outlook of Joseph's industrial cityscapes with a 19th Century longing for romance

\footnotetext{
${ }^{13}$ This resonates with some recent developments in landscape studies, which problematise the centrality of vision in epistemologies of the viewed (Cosgrove, 2008; Macpherson, 2006, 2010).

${ }^{14}$ See, for a culinary example, also The Delights of Delicate Eating (1901).

${ }^{15}$ The latter is dedicated "to the Alpine Club, to whom I should like to point out that there is another and more delightful method of climbing"; for the Alpine Club orthodoxy, see Bainbridge (2020: 91-99); for an overview on the Pennells' role in the history cycling as a modern tourist practice, see Withers and Shea (2016: 19-40).
} 
(Figure 2). Their first arrival in Venice as a married couple in 1884 was tainted with some disappointment arising from the high expectation derived from reading Ruskin's The Stones of Venice:

my first impressions of Venice were gathered in the freezing, foggy station restaurant where J[oseph] and I drank our coffee and yawned, and I would have thought Ruskin a fraud with his purple passage describing the traveller s arrival in Venice upon which I had based my expectations, had I been wide enough awake to think of anything at all, and the hours stretched themselves into centuries before a touch of yellow in the fog suggested a sun shining in some remote world, and we crawled under the cover of one of the dim black boats that emerged vaguely, a shadow from the shadows. (Pennell, 1916: 73-74)

Elizabeth is alluding here to Ruskin's famous word painting, in which he depicted his dramatic entrance to Venice by water in 1851 . In a letter to his father, later included in The Stones of Venice, he writes:

the hills of Arqua rose in a dark cluster of purple pyramids, balanced on the bright mirage of the lagoon; two or three smooth surges of inferior hill extended themselves about their roots, and beyond these, beginning with the craggy peaks above Vicenza, the chain of the Alps girded the whole horizon to the north - a wall of jagged blue, here and there showing through its clefts a wilderness of misty precipices, fading far back into the recesses of Cadore, and itself rising and breaking away eastward, where the sun struck opposite upon its snow, into mighty fragments of peaked light, standing up behind the barred clouds of evening, one after another, countless, the crown of the Adrian Sea, until the eye turned back from pursuing them, to rest upon the nearer burning of the campaniles of Murano, and on the great city, where it magnified itself along the waves, as the quick silent pacing of the gondola drew nearer and nearer. (Bradley, 1955: 124-125; Works, 10: 5) ${ }^{16}$

This "purple passage" is a clear instance of highly skilled romantic writing. But it includes also a set of instructions to experience an immediate visual encounter with the city through "watchful wandering", able to excite Elizabeth as well as any excitable amateur (Kite, 2009). In the same way in which in Modern Painters Ruskin taught his readers to appreciate Turner, the critic encourages here his readers to "discover and distinguish the variety of visual facts that make up the impression of labyrinthine light and shadow", encouraging them to acquire "a particular painterly way of seeing", able to perform "the kind of orderly optical scanning by which a spectator fully sees a picture or scene" (Helsinger, 1982: 20). It is precisely this method of visual analysis that Elizabeth is becoming increasingly wary.

\footnotetext{
${ }^{16}$ See Bainbridge (2020) for the relationship between Venice and the "recesses of Cadore”, or Venice's mountainous horizon; on Ruskin's word-painting, see Landow (1971: 232-236). The "misty precipices, fading back into the recesses of Cadore", seen from a gondola, clearly impressed Amelia Edwards, who transformed them into the "mystic mountains beyond Verona" that she observed while floating in a gondola near Murano (1873: 5).
} 


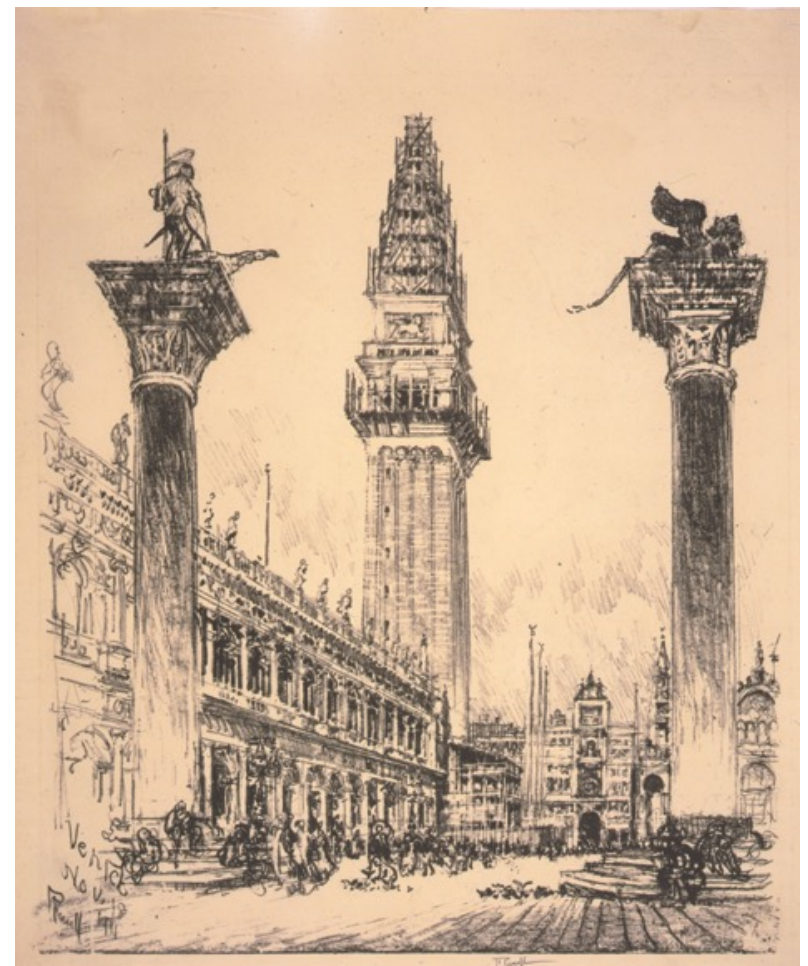

Figure 2 - Joseph Pennell 'Venice Rebuilding the Campanile' (1911)

- Washington DC, Library of Congress, Prints and Photographs Division.

In describing the intellectual life and "café" conversations had with other artists in Rome, she argued that the "quality of the talk was as amazing: bewildering, revolutionary, to anybody who had never heard art talked about by artists, as I never had before I met J[oseph]. All I had thought right turned out to be wrong, all I had never thought of was right, all that was essential to the critic of art, to the Ruskin-bred, had nothing to do with it whatever" (1916: 45-46). Or, in a similar scenario, but this time during the couple's first trip to Venice, a similar conversation led to a new understanding of the city freed from the Ruskin 'straitjacket':

\begin{abstract}
It was a very different past from that which tourists were then bullied by Ruskin into believing should alone concern them in Venice indeed, my greatest astonishment in this astonishing year was that, while the people who were not artists but posed as knowing all about art did nothing but quote Ruskin, artists never quoted him, and never mentioned him except to show how little use they had for him. (ibid: 92)
\end{abstract}

Her issue with Ruskin seems to reside in the idea that Ruskin's orderly process of viewing merely reinforced the value of his literary descriptions against those achieved through painting: according to Elizabeth, Ruskin's method allowed visitors in Venice only to mimic his way of seeing rather than seeing the city for what it was. Her Ruskin-induced disappointment stimulated her to devise new ways of recasting Venice, less concerned the 
bullying regimes of "the big and little volumes by Ruskin upon which the public crowding to Venice based their artistic creed” (ibid: 94).

However, The Stones of Venice continued to possess a pivotal status for tourists in Venice at the turn of the century, and Elizabeth's own experience of the city was still shaped in relation to Ruskin's own. She embodied, along with Joseph, that essentially Ruskinian anti-tourist nervousness towards the burgeoning heritage industry so keen to restore and over-restore Venice transforming it into a museum. In a letter to his sister in June 1883, Joseph wrote:

Oh what an awful sell it is - coming in on a long bridge - and not from Mestre in a gondola - à la Ruskin (see somewhere in Stones of Venice) - and that beastly black hearse to get into - which rocks like a hammock (I hate hammocks) and smelly canals - and howling women and St. Mark's all polished up and looking like a new town house - and a fellow with a swelled head - those were my first impressions of Venice - and I carried them for several days, voting myself and not the place a sell - and the next morning when I go out nothing but pittori-pittori ${ }^{17}$ - almost as many as the pieces of the ugly old red brick washed-out marble that the palace is built of. (1929, 1: 93-94)

These first impressions have actually little to do with Ruskin's sophisticated political interpretation of the picturesque as a feeling rather than a style, embodying a "sympathetic observation of 'suffering, of poverty or decay, nobly endured by unpretending strength of heart" (Macarthur, 1997: 133). Ruskin is here simply reduced to a generic cliché haunting the reception of The Stones of Venice.

The Pennells were more comfortable in closer proximity to the real world they experienced in Venice and elsewhere, overcoming the nationalistic objectification of the picturesque operated by seemingly self-conscious writers like Ruskin. After a terrifyingly cutting review of Whistler's 'Nocturne in Black and Gold: The Falling Rocket' (1875), exhibited at London's Grosvenor Gallery, the painter accused Ruskin of libel in a famous lawsuit. In his Fors Clavigera, Ruskin dismissed the work in these acerbic terms: "I have seen and heard much of Cockney impudence before now, but never expected to hear a coxcomb ask 200 guineas for flinging a pot of paint in the public's face" (Works, 29: 581; Clarke, 2005: 78). The trial is accounted for in the Pennells' biography of Whistler almost verbatim, ultimately dismissing Ruskin as mad (Pennell and Pennell, 1908, 1: 229-245; Merrill, 1992; Parkes, 1999).

The 1878 trial at the Old Bailey ruled in Whistler's favour but awarded him, however, only a symbolic farthing in damages. For Ruskin, the Turnerian beauty of the Thames was transformed in Whistler's 'Nocturne in Black and Gold' into an intolerable exaltation of the industrial pollution and degenerate landscape of the river. The painting only served as a piece of art, produced for art's own sake, apparently not one made with a didactic or moral purpose. Although Ruskin's promotion of the idea that aesthetic potentiality was somehow denied and thwarted by 19 th Century capitalism and industrialisation, a notion which has been berated for being apparently 'moralistic', Ruskin's appeal to morality in fact should be regarded with more nuance and not along narrow ethical lines. As Fuller has reminded us, for Ruskin morality "encompassed everything we would identify under such categories as human affections and emotions, structures of feeling, indeed the whole rich terrain of imaginative and symbolic thought" (1997: 15). The Whistler v. Ruskin trial, nevertheless,

\footnotetext{
${ }^{17}$ Meaning, 'painters [and more] painters'.
} 
embodied the clash between the new modernist approach to art, which was not incidentally unique to Whistler nor the Pennells, with the seemingly outdated, albeit persuasive, doctrine of Ruskin. The dispute heralded a decline in Ruskin's authority, even if his doctrine persisted as a frame of reference for Pennell in "conditioning his response to the powerful artistic appeal of the industrial landscape" (Palumbo, 1986: 40). Ruskin was untrusting of the avantgarde and "the general tendency of modern art under the guidance Paris" because, according to him, it was in pursuit of sensuous pleasure and not of a beauty able to elicit a moral response, retorting "I take no notice of the feelings of the beautiful, which we share with flies and spiders" (Works, 4: 64). The clashes outlined here should not be insisted upon as a categorical rejection of Ruskin and nor should the stance taken by the Pennells or Whistler be seen as personally derogatory towards Ruskin either. The clash is representative of a generational shift of opinion and a clash of two different aesthetic categories.

Where, instead, a clearer alignment is found between Ruskin and the Pennells' methods, is in their shared rejection of the Venetian heritage machine in possession only of an affected knowledge of art and history able to produce only modern tourists without any aspiration to modernity. However, despite Elizabeth's labelling of Ruskin as a "fraud", he remains the central point of reference from which her more 'modern' understanding of and writing about art begin. Albeit begrudgingly, she ultimately refers to Ruskin as the "prophet of art", a label that she is unable to fully acquire for herself (Pennell, 1916: 46). The context in which that formula appears, however, reveals in fact a direct, albeit simplistic, attack upon the art of connoisseurship, embodied by Giovanni Morelli, whom she sees, hastily and uncritically, as "threatening to succeed Ruskin" in dealing with topics such "history, dates, periods, schools, sentiment, meaning, attributions" instead of art in its own right (ibid). ${ }^{18}$

\section{Recasting the Modern Venetian Landscape}

At the turn of the 2oth Century, the contribution of Joseph and Elizabeth Pennell to debates about how Venice should be seen argued for a more subjective view upon the city freer from the clichés accumulated through generations of visual and literary representations. Along with Whistler, Sargent, James, and others, they became the conduit of a new Anglo-American voice, overheard from the conversations uttered within the overlapping circles of likeminded individuals, meeting at Palazzo Barbaro, Palazzo Dario, Ca' Rezzonico, or Casa Jankovitz (Figure 3), the humble abode of the realist painters known as the Duveneck Boys (Schwander, 2008: 21; Wylie, 1989). At times, this voice sounded Ruskinian, despite its abused aesthetic epistemology; at others, it resonated more with real life experiences, including the grimy reality of the everyday, in sharp dissonance with Ruskin's account that they tended to judge as too oleographic.

The contrast inherent in this debate allows us to trace a progression from a way of seeing Venice towards a way of living it. The Pennells were able to develop their image of Venice by moving away from its stereotyped iconographic legacy and towards a new phenomenological outlook, which could be termed, following Cosgrove (1998), as non-representational or nonpictorial. The same dichotomy re-emerges in Lowenthal's need to identify the range of responses to "key symbolic landscapes - landscapes that perennially catch the attention of mankind and seem to stand for, reflect or incorporate, the meaning and purpose of life itself" (Lowenthal, 1967: 2). Following this need, the Pennells' quest for Venice yielded to a search

\footnotetext{
${ }^{18}$ For the complex links between Ruskin and Morelli, often misread, see Hinojosa (2009: 93-95).
} 
for a more substantive meaning of the Venetian landscape (Olwig, 1996), forged by real people and not simply by picturesque figurines featured in some sentimental fantasy of a bygone age, as in Emma Ciardi's canvases then popular on the London art market (Zerbi, 2003: 20 - Figure 4).

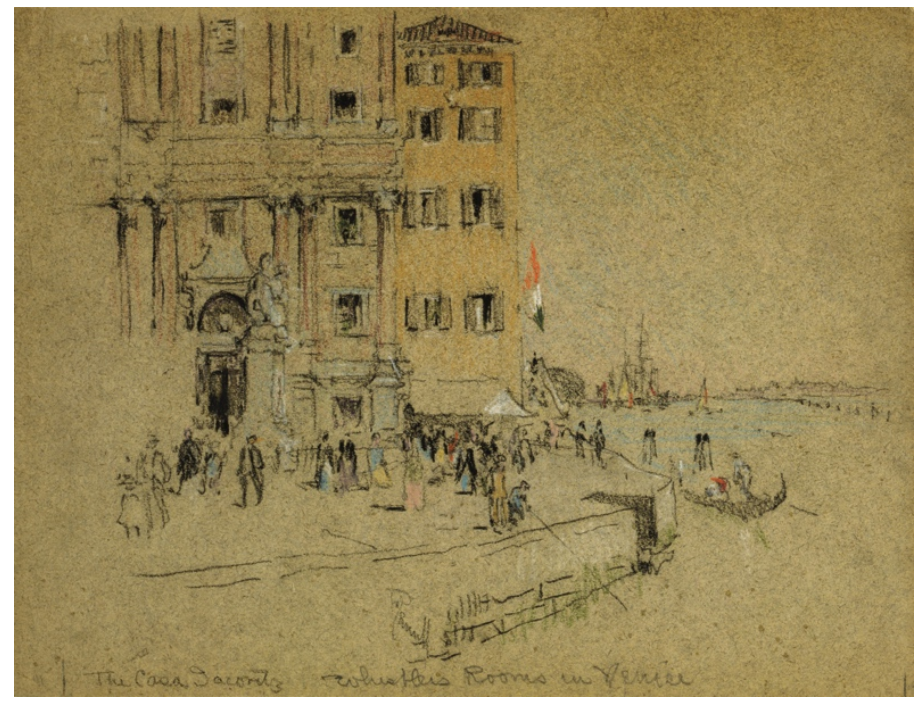

Figure 3 - Joseph Pennell 'The Casa Jankovitz - Whistler's Rooms in Venice' (1901) - Washington DC, Library of Congress, Prints and Photographs Division.

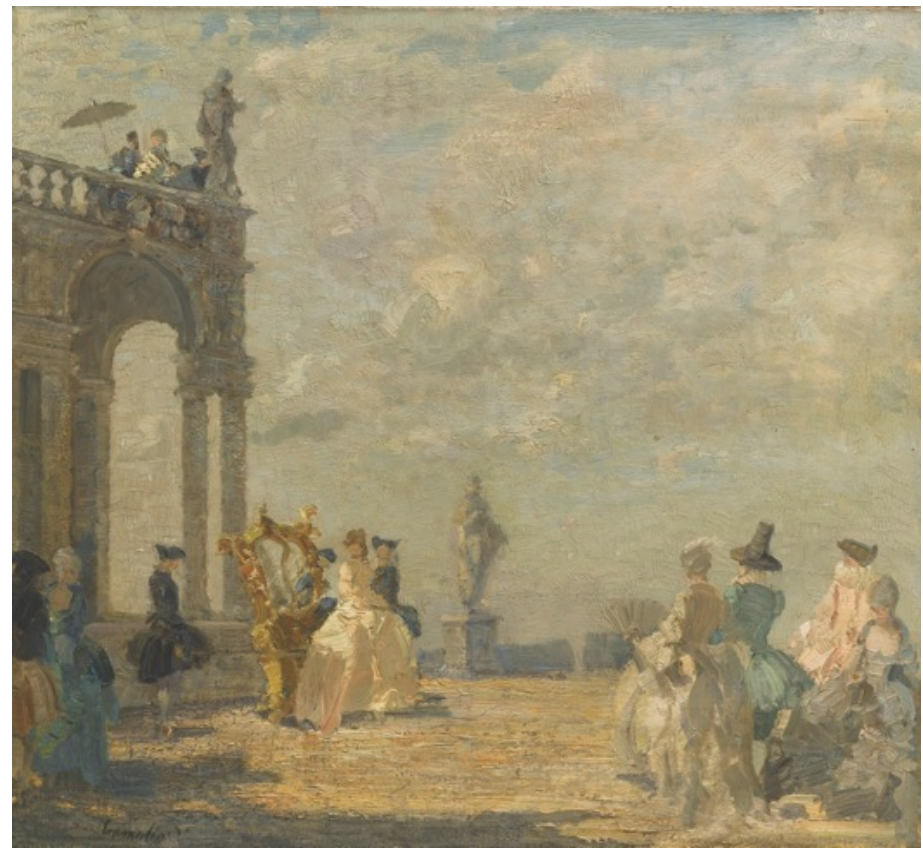

Figure 4 - Emma Ciardi ‘The Festival Arrival’ (1925) - Private Collection. 
Realism in art and realism in writing about art were the Pennells' way of accommodating a somewhat anti-Ruskinian sentiment which elevated the body over the primacy of the eye a body able to do the city by meandering within its everyday hustle and bustle. Whistler and Joseph were also concerned, as Elizabeth frequently reminds us, with "art as a trade" - a "trade which creates beauty", moulding the city anew through the craftmanship of painting (1916: 46). Instead of seeing the fabric of the Venetian landscape as a problem of duplicity, urging us to choose between a way of seeing and a way of living, we should begin to see it as an example of a shuttling through landscape, where oppositions between vision and practice, representation and embodiment, coalesced (Cosgrove, 2003). As Daniels puts it, "we should beware of attempts to define landscape, to resolve its contradictions; rather we should abide in its duplicity" (1989: 218).

Against "the big and little volumes by Ruskin upon which the public crowding to Venice based their artistic creed", the Pennells and their circle arguably reduced the complexity of Ruskin's work to a set of formulaic clichés in order to demystify the aesthetic manoeuvres of the Victorian critic as convoluted, good only for staging preposterous visits to the shrine of art and architecture. In reporting a conversation held at Venice's Caffè Florian with Frank Duveneck and others, Elizabeth wryly recalled:

They couldn't, for the life of them, see why the place had been so cracked up by Ruskin. Nothing was right. The Piazza was just simply the town's meeting place and centre of gossip, like the country village store, only on a more architectural and uncomfortable scale. (1916: 99; Figure 5)

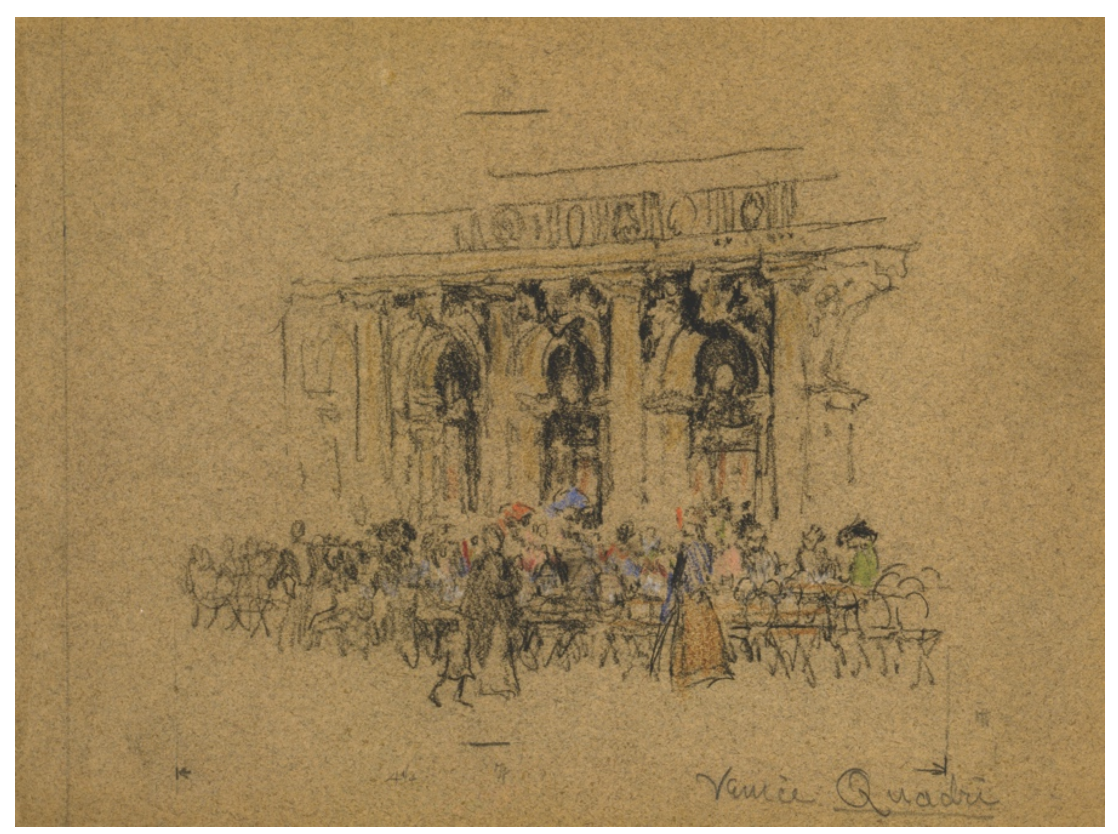

Figure 5 - Joseph Pennell 'Venice Quadri' (1901) - Washington DC, Library of Congress, Prints and Photographs Division. 
How one was to see Venice was no longer preordained by following leaders like Ruskin or Byron "like sheep", and no more was one to be plagued by the "horrible conscientiousness" or the "deadly determination to see the correct things and to think the correct thoughts about them" (ibid: 269). The beauty of Venice was to be recorded by venturing to explore "fresh fields", as modern individuals living in a modern city, whose ancient "architectural" fabric, so inflated with Ruskinian hot air, was just another "unconformable" nuisance in the paradise of cities.

\section{BIBLIOGRAPHY}

Ackroyd, P (2009) Venice: pure city, London: Chatto and Windus

Bainbridge, W (2018) 'The rock behind the lagoon: the Dolomites in the iconography of Venice', in Vallerani, F and Visentin, F (eds) Waterways and the cultural landscape, Abingdon: Routledge: 104-21

Bainbridge, W (2020) Topographic memory and Victorian travellers in the Dolomite Mountains: peaks of Venice, Amsterdam: Amsterdam University Press

Bosworth, R.J.B (2015) Italian Venice: a history, New Haven, London: Yale University Press

Bradley, J.L (ed) (1955) Ruskin's letters from Venice, 1851-1852, New Haven: Yale University Press

Buzard, J (1991) 'The uses of Romanticism: Byron and the Victorian continental tour', Victorian Studies v35 n1: 29-49

Buzard, J (1993) The beaten track: European tourism, literature, and the ways to culture, 180o1918, Oxford: Oxford University Press

Bye, A.E (1926) 'The memorial exhibition of the work of Joseph Pennell', Bulletin of the Pennsylvania Museum v22 n106: 221-26

Byron, G.G (2013) Childe Harold's pilgrimage (Thompson, A.H [ed]), Cambridge: Cambridge University Press

Chaucer, G (2008) The riverside Chaucer (Benson. L. D [ed]), Oxford: Oxford University Press

Clegg, J (1981) Ruskin and Venice, London: Junction Books

Collins, W (1879) The haunted hotel: a mystery of modern Venice, London: Chatto and Windus

Cosgrove, D.E (1979) 'John Ruskin and the geographical imagination', Geographical Review v69 n1: $43-62$

Cosgrove, D.E (1998) Social formation and symbolic landscape, Madison: University of Wisconsin Press 
Cosgrove, D.E (2003) 'Landscape and the European sense of sight: eyeing nature', in Anderson, K, Domosh, M, Pile, S and Thrift N (eds) Handbook of cultural geography, London: SAGE: $249-68$

Cosgrove, D.E (2008) Geography and vision: seeing, imagining and representing the world, London, New York: I.B. Tauris

Crawford, F.M (1905) Gleanings from Venetian history (2 volumes), New York: The Macmillan Company

Damien, E (2010) 'Ruskin vs. Murray: battles for tourist guidance in Italy', Nineteenth-Century Contexts v32 n1: 19-30

Daniels, S (1989) 'Marxism, culture, and the duplicity of landscape', in Peet, R and Thrift, N (eds) New models in geography: the political-economy perspective (2 volumes), London: Routledge v2: 196-220

Davis, R.C and Marvin, G (2004) Venice, the tourist maze: a cultural critique of the world's most touristed city, Berkeley: University of California Press

Denker, E (2003) Whistler and his circle in Venice, London: Merrell

Dickens, C (1846) Pictures from Italy, London; Bradbury and Evans

Dragicevich, P and Hardy, P (2020) Lonely Planet Venice and the Veneto, Oakland, London: Lonely Planet Publications

Edwards, A.B (1873) Untrodden peaks and unfrequented valleys, a midsummer ramble in the Dolomites, London: Longmans, Green and Co.

Fletcher, C.A and Spencer, T (eds) (2005) Flooding and environmental challenges for Venice and its lagoon: State of Knowledge, Cambridge: Cambridge University Press

Fuller, P (1997) 'The geography of mother nature', in Cosgrove, D.E and Daniels, S (eds) The iconography of landscape: essays on the symbolic representation, design and use of past environments, Cambridge: Cambridge University Press: 11-31

George, H (1971) 'Turner in Venice', The Art Bulletin v53 n1: 84-87

Goodwin, G and Johnston, G (2013) 'Guidebook publishing in the nineteenth century: John Murray's handbooks for travellers', Studies in Travel Writing v17 nı: 43-61

Graham, W (2003) 'Pictures for texts', The Henry James Review v24 n1: 1-26

Greenfield, K.R (1939) 'Commerce and new enterprise at Venice, 1830-48', The Journal of Modern History vi1 n3: 313-33

Halsby, J (1999) Venice, the artist's vision: a guide to British and American painters, London: Unicorn 
Hanley, K (2010) 'Ruskin, Venice and nineteenth-century cultural travel: the quest for restoration', in Hanley, K and Sdegno, E (eds) Ruskin, Venice and nineteenth-century cultural travel, Venice: Cafoscarina: xvii-xxxii

Hartley, L.P (1967) The novelist's responsibility, London: Hamish Hamilton

Helsinger, E.K (1982) Ruskin and the art of the beholder, Cambridge: Harvard University Press

Hewison, R (2000) 'Ruskin and the Gothic revival: his research on Venetian architecture', in Hewison, R (ed) Ruskin's artists: studies in the Victorian visual economy, Aldershot, Brookfield: Ashgate Publishing: 53-70

Hewison, R (2009) Ruskin on Venice: the paradise of cities, New Haven: Yale University Press

Hinojosa, L.W (2009) The Renaissance, English cultural nationalism, and modernism, 18601920, New York: Palgrave Macmillan

Holcomb, A.M (1988) 'Turner and Rogers' "Italy” revisited', Studies in Romanticism v27 n1: 63-95

Honour, H and Fleming, J (1991) The Venetian hours of Henry James, Whistler and Sargent, Boston: Little, Brown

James, H (1909) Italian hours, Boston, New York: Houghton Mifflin Company

Jones, K.M (2016) Elizabeth Robins Pennell, nineteenth-century pioneer of modern art criticism, London: Routledge

Keppel, F.P (1907) Joseph Pennell: etcher, illustrator, author, New York: Frederick Keppel and Co.

Kite, S (2009) “Watchful wandering”: John Ruskin's strayings in Venice', Journal of Architectural Education v62 n4: 106-14

Landow, G.P (1971) The aesthetic and critical theories of John Ruskin, Princeton: Princeton University Press

Lowenthal, D (1967) Environmental perception and behavior, Research Paper nıo, Chicago: Department of Geography, University of Chicago

Macarthur, J (1997) ‘The heartlessness of the picturesque: sympathy and disgust in Ruskin's aesthetics', Assemblage n32: 127-41.

MacCauley, E.A (ed) (2004) Gondola days: Isabella Stewart Gardner and the Palazzo Barbaro circle, Boston: Isabella Stewart Gardner Museum

Macpherson, H (2006) 'Landscape’s ocular-centrism: and beyond?', in Tress, B, Tress, G, Fry, $\mathrm{G}$ and Opdam, $\mathrm{P}$ (eds) From landscape research to landscape planning: aspects of integration, education and application, Dordrecht, New York: Springer: 95-104 
Macpherson, H (2010) 'Non-representational approaches to body-landscape relations', Geography Compass v4 n1: 1-13

Madricardo, F and Donnici, S (2014) 'Mapping past and recent landscape modifications in the Lagoon of Venice through geophysical surveys and historical maps', Anthropocene v6: 86-96

McGann, J.J (ed) (1994) Lord Byron: the major works, Oxford, New York: Oxford University Press

Merrill, L (1992) A pot of paint: Whistler v. Ruskin, Washington: Smithsonian Institution Press

Morenus, L.S (2004) 'Joseph Pennell and the art of transfer lithography', Print Quarterly v21 n3: $248-65$

Morris, J (1960) Venice, London: Faber and Faber

Norwich, J.J (2004) Paradise of cities: Venice in the 19th Century, New York: Vintage Books

Nunn, P.G (2000) 'The “woman question”: Ruskin and the female artist', in Hewison, R (ed) Ruskin's artists: studies in the Victorian visual economy, Aldershot: Ashgate Publishing: 16784

Olwig, K.R (1996) 'Recovering the substantive nature of landscape', Annals of the Association of American Geographers v86 n4: 630-53

P, L.E (1927) ‘The Joseph Pennell memorial exhibition', The Bulletin of the Cleveland Museum of Art v14 n4: 66-68

Palmowski, J (2002) 'Travels with Baedeker: the guidebook and the middle classes in Victorian and Edwardian England', in Koshar, R (ed) Histories of leisure, Oxford, New York: Berg: 105-30

Palumbo, A.C (1986) 'The cathedral and the factory: the transformation of work in the art of Joseph Pennell', IA: The Journal of the Society for Industrial Archeology v12 n2: 39-50

Parkes, A (1999) 'A sense of justice: Whistler, Ruskin, James, impressionism', Victorian Studies v42 n4: 593-629

Pennell, E.R (1884) Life of Mary Wollstonecraft, Boston: Roberts Brothers

Pennell, E.R (1901) The delights of delicate eating, New York: The Saalfield Publishing Company

Pennell, E.R (1916) Nights: Rome, Venice, in the aesthetic eighties; London, Paris, in the fighting nineties, Philadelphia, London: J.B. Lippincott Company

Pennell, E.R (1929) The life and letters of Joseph Pennell (2 volumes), Boston: Little, Brown, and Company 
Pennell, E.R and Pennell, J (1898) Over the Alps on a bicycle, London: T. Fisher Unwin

Pennell, E.R and Pennell, J (1908) The life of James McNeill Whistler (2 volumes), London: W. Heinemann

Pennell, E.R and Pennell, J (1909) French cathedrals, monasteries and abbeys, and sacred sites of France, London: T. Fisher Unwin

Pennell, J (1895) Modern illustration, London, New York: George Bell and Sons

Pennell, J (1896) The illustration of books: a manual for the use of students, notes for a course of lectures at the Slade School, University College, London: T. Fischer Unwin

Pennell, J (1912) The great New York, Boston: Le Roy Phillips

Pennell, J (1913) San Francisco the city of the Golden Gate, being twenty-five reproductions in photogravure from etchings and drawings, Boston: Le Roy Phillips

Pennell, J (1913a) Venice, the city of the sea, London: T.N. Foulis

Pennell, J (1914) Haunts of old London being twenty-five etchings of literary and historical London in photogravure, London: T.N. Foulis

Pennell, J (1919) Etchers and etching: chapters in the history of the art, together with technical explanations of modern artistic methods, New York: The Macmillan Company

Pennell, J (1921) The graphic arts: modern men and modern methods, Chicago: Published for the Art Institute of Chicago by the University of Chicago Press

Pennell, J (1925) The adventures of an illustrator, mostly in following his authors in America and Europe, Boston: Little, Brown, and Company

Pennell, J and Pennell, E.R (1885) A Canterbury pilgrimage, London: Seeley and Company

Pennell, J and Pennell, E.R (1888) Our sentimental journey through France and Italy, London: Longmans, Green, and Co.

Pertot, G (1988) Venezia 'restaurata': centosettanta anni di interventi di restauro sugli edifici veneziani, Milan: Franco Angeli

Redford, B (1996) Venice and the grand tour, New Haven: Yale University Press

Rogers, S (1854) The poetical works of Samuel Rogers, E.H. Butler and Co.

Ross, M.L (1994) Storied cities: literary imaginings of Florence, Venice, and Rome, Westport: Greenwood Press

Ruskin, J (1903-1912) The library edition of the works of John Ruskin (Cook, E.T and Wedderburn, A [eds]) (39 volumes), London: George Allen

Sand, G (1833) Leone Leoni, Paris: Librairie Blanchard 
Sandy, M (2021) “Thy wreck a glory": Venice, subjectivity, and temporality in Byron and Shelley and the post-Romantic imagination', in Laniel-Musitelli, S and Sabiron, C (eds) Romanticism and time, Cambridge: Open Book Publishers: 209-28

Schuyler Van Rensselaer, M (1892) English cathedrals: Canterbury, Peterborough, Durham, Salisbury, Lichfield, Lincoln, Ely, Wells, Winchester, Gloucester, York, London (illustrated by Pennell, J), New York: The Century Co.

Schwander, M (2008) 'Images of Venice: history and myths of a city', in Schwander, M (ed) Venice: from Canaletto and Turner to Monet, Ostfildern: Hatje Cantz: 11-28

Settis, S (2016) If Venice dies (translated by Naffis-Sahely, A), New York: New Vessel Press

Shapiro, H.I (1972) Ruskin in Italy: letters to his parents, 1845, Oxford: Clarendon Press

Shelley, M (1826) 'Art. IV. - 1. the English in Italy. 3 Vols. London. 1826. 2. Continental adventures. A novel. 3. Vols. London. 1826. 3. Diary of an ennuyée. London. 1826', Westminster Review v6: 325-41

Stern, L (1894) A sentimental journey through France and Italy, London: Dent

Tucker, P (1996) “Right conclusions”: seven unpublished letters (1845-46) from John Ruskin to John Murray', Annali d'Italianistica v14: 582-621

Withers, J and Shea, D.P (2016) Culture on two wheels: the bicycle in literature and film, Lincoln: University of Nebraska Press

Wylie, E (1989) Explorations in realism, 1870-1880: Frank Duveneck and his circle from Bavaria to Venice, Framingham: Danforth Museum of Art

Young, M.S (1970) 'The remarkable Joseph Pennell', American Art Journal v2 n1: 81-91

Zerbi, M (2003) 'Tra ombra e sole: paesaggio di una pittrice veneziana nel mondo', in Zerbi, $\mathrm{M}$ and Esposito, M (eds) Emma Ciardi: pittrice veneziana tra '8oo e '9oo: paesaggi tra ombra e sole, Treviso: Canova: 17-25 